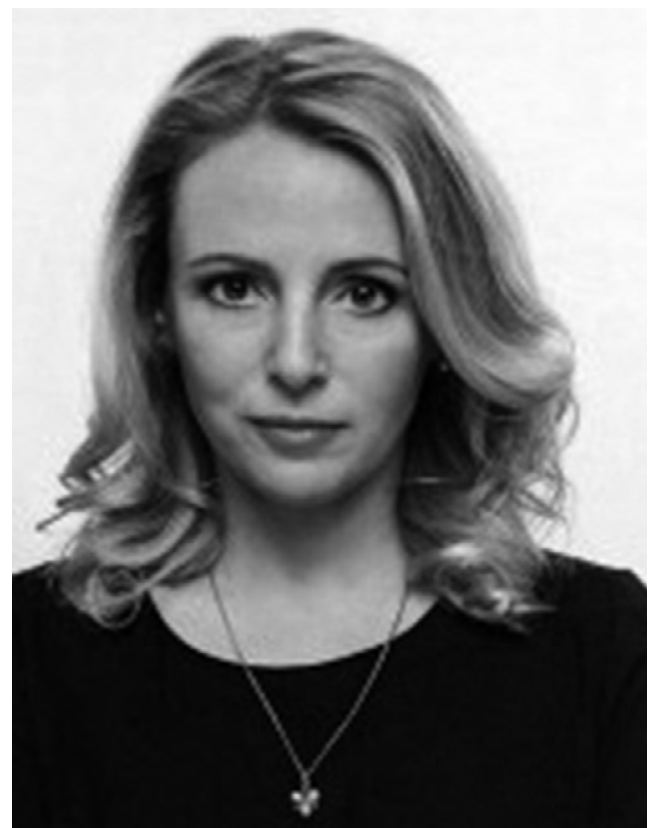

UDC: 330.341.1:351

Yuzkova Olena Ivaniona,

PhD Candidate, Tavriyskiy National University, specialization "Public Management", 02068, Kyiv, Str. Drahomanova, 31B, tel.: (099) 079 46 80, e-mail: e.yuzkova@gmail.com

ORCID: 0000-0002-0344-9693

Юзъкова Олена Іванівна,

аспірантка, Таврійський національний університет за спеціальністю "Державне управління”, 02068, м. Київ, вул. Драгоманова, 316, тел.: (099) 07946 80, e-mail: e.yuzkova@gmail.com

ORCID: 0000-0002-0344-9693

Юзъкова Елена Ивановна, аспірантка, Таврийский национальный университет по специальности "Государственное управление”, 02068, г. Киев, ул. Драгоманова , 316, тел.: (099) 07946 80,e-mail: e.yuzkova@gmail.com.

ORCID: 0000-0002-0344-9693

DOI https://doi.org/10.32689/2617-2224-2019-16-1-250-259

\title{
PECULARITIES OF INNOVATION LEADERSHIP DEVELOPMENT IN PUBLIC MANAGEMENT
}

Annotation: The article describes the idea of innovation leadership in public administration and widens understanding of the role of innovative leaders in strategic public management in modern Ukraine, as well as identifies the profile of an innovative leader in public management and the factors which may help public institutions in identifying key directions in development of innovative leaders at the state level.

In the modern world leadership is being transformed. Modern leader doesn't offer ready-made solutions but lets his team work them out, his power is not in seal but in open recognition his team members' work, in respect and achievements. New leadership is based on understanding of own mission, realizing personal strengths and developing an effective team. Key difference of an innovative leader - ability to see the future, inspire and lead the team, create and implement innovations in cities, regions, country. Necessity to move to innovation leadership model and strategic planning in public management in improving mechanisms of public management is also supported by statistics, which you can find in the article.

Goals, tasks and functions of the state, strategies of innovation leadership development are becoming the factors that influence formation and functioning 
of public management mechanisms. There are examples of countries-leaders as for the right thinking concerning peculiarities of public management system development based on innovation leadership as a constituent of improving public management system in Ukraine. To prove theoretic methodological approaches of transition to model of innovative leadership in public management it is necessary to describe a frame of innovation leadership in public management. And using this frame as a basis of the model it is possible to create a system of innovative leaders in public management development who will be able to make necessary steps in further development of the country.

Keywords: innovation leadership, public management, leadership development, transformation leadership.

\section{ОСОБЛИВОСТІ РОЗВИТКУ ІННОВАЦІЙНОГО ЛІДЕРСТВА В СИСТЕМІ ДЕРЖАВНОГО УПРАВЛІННЯ}

Анотація. Розкрито поняття інноваційного лідерства в державному управлінні та розширено розуміння того, яку роль мають відігравати інноваційні лідери у стратегічному управлінні державою в сучасній Україні, а також розглядаються профіль інноваційного лідера в державному управлінні та ті фактори, які допоможуть державним інституціям у визначенні ключових напрямів розвитку інноваційних лідерів на державному рівні.

Лідерство в сучасному світі трансформується. Сучасний лідер не дає готових рішень, але дає змогу своїй команді розробити їх, його сила - не в повноваженнях, а на відвертому визнанні роботи членів команди, поваги та досягненнях. Нове лідерство базується на розумінні власної місії, усвідомленням власних сильних сторін та розвитку ефективної команди. Ключова відмінність інноваційного лідера - здатність дивитись у майбутнє, надихати та вести за собою команду, створювати та втілювати інновації в містах, регіонах та державі. Необхідність переходу до моделі інноваційного лідерства в державному управлінні та застосуванні стратегічного планування в удосконаленні механізмів державного управління підтверджує і наведена статистика.

Цілі, завдання, функції держави, стратегії щодо розвитку інноваційного лідерства стають факторами впливу на формування та функціонування механізмів державного управління. Свідченням є приклади країн-лідерів щодо правильності осмислення особливостей розвитку системи державного управління на засадах інноваційного лідерства як складової для вдосконалення системи державного управління в Україні. Обгрунтовуючи теоретико-методичний підхід переходу до моделі інноваційного лідерства в державному управлінні, необхідно визначити межу інноваційного лідерства в державному управлінні, що сприятиме створенню системи розвитку інноваційних лідерів в державному управлінні, які зможуть вдало робити необхідні подальші кроки для розвитку країни.

Ключові слова: інноваційне лідерство, державне управління, розвиток лідерів, трансформаційне лідерство. 


\section{ОСОБЕННОСТИ РАЗВИТИЯ ИННОВАЦИОННОГО ЛИДЕРСТВА В СИСТЕМЕ ГОСУДАРСТВЕННОГО УПРАВЛЕНИЯ}

Аннотация. Раскрывается понятие инновационного лидерства в государственном управлении и расширяется понимание того, какую роль должны играть инновационные лидеры в стратегическом управлении государством в современной Украине, а также рассматриваются профиль инновационного лидера в государственном управлении и те факторы, которые помогут государственным институтам в определении ключевых направлений развития инновационных лидеров на государственном уровне.

Лидерство в современном мире трансформируется. Современный лидер не дает готовых решений, но дает возможность своей команде разработать их, его сила - не в полномочиях, а в открытом признании работы членов команды, уважении и достижениях. Новое лидерство базируется на знании собственной миссии, понимании собственных сильних сторон и развитии эффективной команды. Ключевое отличие инновационного лидера - способность смотреть в будущее, вдохновлять и вести за собой команду, создавать и внедрять инновации в городах, регионах, стране. Необходимость перехода к модели инновационного лидерства в государственном управлении и использовании стратегического планирования в совершенствовании механизмов государственного управления подтверждает и приведенная статистика.

Цели, задачи, функции государства, стратегии касательно развития инновационного лидерства становятся факторами влияния на формирование и функционирование механизмов государственного управления. Свидетельством этого есть примеры стран-лидеров касательно правильности осмысления особенностей развития системы государственного управления на основе инновационного лидерства как составляющей для совершенствования системы государственного управления в Украине. Обосновывая теоретико-методические подходы перехода к модели инновационного лидерства в государственном управлении, необходимо обозначить рамку инновационного лидерства в государственном управлении, что будет способствовать созданию системы развития инновационных лидеров в государственном управлении, которые смогут удачно сделать необходимые дальнейшие шаги для развития страны.

Ключевые слова: инновационное лидерство, государственное управление, развитие лидеров, трансформационное лидерство.

Problem statement. The relevance of the topic is determined by several factors. First, there is a lack of knowledge of the topic of leadership in public administration, and even more of the role of the leader in ensuring the effective func- tioning of public authorities. Secondly, the development of market mechanisms and post-industrial economy requires modern commercial and government organizations to adapt quickly to the changing turbulent environment. One 
of the most necessary elements of success in the effective operation of organizations is the presence and education of leaders who will be able not only to see the need for changes in the existing system, but also to create conditions for their implementation. Thus, understanding the role of innovative leaders in the strategic management of the state in modern Ukraine will help state institutions in determining the key areas of development of leaders within the organization.

Goals, objectives, functions of the state, strategies for the development of innovative leadership also become factors of influence on the formation and functioning of public administration mechanisms. This is confirmed by the examples of the leading countries regarding the correct understanding of the features of the development of public administration on the basis of innovative leadership as a component for improving the system of public administration in Ukraine.

Changing the historical inertia in which the country has moved so far is too difficult. That is why there should be a formation of people who are able to ensure the continuity of the vision of the future of Ukraine and to overcome obstacles the most difficult of which is the culture of governance. The world is now becoming even more complex under the influence of technology, geopolitics and other factors that require Ukraine not just to move forward, but to apply extra efforts. Therefore, the country urgently needs innovative leaders who are able to change the space in which they are located. And this leads to a rethinking of the state as such: what is its role in people's lives?
What should our country be like? Who are we as Ukrainians in the global context and what do we create for the world?

The solution of the goals and objectives set in the study is of great scientific, applied and social importance. In the strategic context it is the institutional support of innovative development of leadership at the state level; and as a tactical task it is the formation of an appropriate system at the level of personality, in which the elements of the system are charismatic leaders (but it is innovative, in which transformational abilities). Such leaders understand not only "how the system is built", but also what tool needs to be applied to adjust this or that process, how, changed something one can affect everything else. After all, innovative leadership answers these questions.

Analysis of recent research and publications. Significant scientific and practical interest is raised by the issues of determining the goals, objectives, functions of the state and strategies for the development of innovative leadership as factors of influence on the formation and functioning of public administration mechanisms, but many of their theoretical, methodological and practical aspects remain insufficiently developed and debated. The lack of an integrated approach to these scientific issues actualizes their importance for the socio-economic development of Ukraine.

In determining the author of this article the prospects of forming a strategy for the development of innovative leadership the scientific works on the definition of the leadership hierarchy of the following leading foreign 
scientists are important: U. Blank, D. Collins, K. Levin, A. Fayol, G. Ford, G. Strogdill, etc. The scientific works of such local scientists as V. Alekseev, N. Honcharuk, P. Zhuravliov, V. Oluiko, T. Pashko, T. Podlesnaya, I. Surai and others are devoted to the problems of leadership development in the public service of Ukraine. The analysis of literary sources on the substantiation of the theory of leadership allows us to come to the conclusion that the theoretical and applied aspects of the formation and functioning of public administration mechanisms aimed at initiating positive changes in the activities of public authorities through a change in the perception of the concept of leadership and its implementation are laid in the scientific works of Yu. V. Kovbasiuk, M. I. Piren, A. P. Rachynskyi.

The purpose of the article is to substantiate the theoretical and methodological approaches to the transition to the model of innovative leadership in public administration and the need for strategic planning in improving public administration mechanisms in the context of a comprehensive reform of the relevant system.

Presentation of the main material. The phenomenon of leadership in the general context was considered through the following theories:

1. Personal qualities of the leader (Cowes and Poser; Warren Bennis and; O'Toole).

2.Behavioral theory (D. McGregor; K. Levin; R. Likert, R. Tannenbaum and. Schmidt; R. Blake and D. Mouton; of D. Goleman, D. Hand and. Torbert). 3. Situational theories (F. Fiedler; P. Hersey and C. Blanchard; C. Cameron and R. Quinn and others).
Technological innovations, market changes, blurring of borders, globalization of the economy contribute to the emergence of a new type of leaders. Leadership in the modern world is transforming. The modern leader is no longer a dictator, but an inspirer, who does not give ready - made solutions, but allows his team to develop them, his strength is not in the powers, but in the frank recognition of the work of team members, respect and achievements. The new leadership is based on understanding of your own mission, understanding your own strengths and developing an effective team. The key difference of an innovative leader is the ability to look to the future, inspire and lead the team, create and implement innovations in cities, regions and the state.

Innovative leadership means:

- transformational innovation leadership [1];

- leadership in situations of change [1];

- team leadership [1];

- use of mentoring for the development of followers [1].

Innovative leaders do not go the familiar way, and pave the new, most often - experimentally in a completely unfamiliar environment.

Since 2014, successful business representatives in Ukraine - recognized leaders-have - started to work in key positions in ministries and state enterprises. Representatives from different sectors of the economy (both financial and non-financial) who have significant achievements are invited to the public service (they are invited, but do not try at any cost to get a position). Open competitions were introduced for this purpose. Thanks to them, several dozen 
business leaders found themselves in government positions. Four years later, some of them resigned, some adapted to the existing system and were unable to demonstrate sufficient efficiency. Among the most resonant events it is possible to allocate Natalia Yaresko's appointment to a position of the Minister of Finance and Aivaras Abromavichus - to the position of the Minister of Economy. According to estimates of VoxUkraine, the Cabinet of Arseniy Yatsenyuk for $40 \%$ consisted of business representatives. But there are several of them, such as Maksym Nefiodov (Deputy Minister of Economic Development and Trade of Ukraine), Ihor Korhovyi (Director General of the Directorate of strategic planning and European integration of the Ministry of regional development, construction and housing), Yulia Zaichenko (Director General of the Directorate of strategic planning and European integration of the Ministry of justice of Ukraine), Anna Novosad (Director General of the Directorate of strategic planning and European integration of the Ministry of education and science of Ukraine), etc., who still remain in the system of public administration, trying, as far as possible, to accelerate changes. It would seem that these people, who had all the characteristics of innovative leaders in business, should be successful in a broader context. But experience has shown that such movement is not always successful. Of course, it is important to take into account that Ukraine has its own unique circumstances (the loss of part of the territories, the ongoing external military aggression against the country and the constant risk of its escalation), which place a heavy burden on the economy and cannot be ignored by the country's leadership in making decisions aimed at improving the welfare of citizens. But, even taking into account these circumstances, it is clear that the skills that make a person successful in public administration and in business are different. Moreover, sometimes they are incredibly different. If in business decision-making it is impossible to rely on a coordinated strategy, detailed market analysis, self-selected team, or postpone the decision, if the risks are large, then in public administration there is often no single coordinated position, there is not enough data and time to make a decision, therefore, another approach is necessary for the development of innovative leaders.

The need to move to the model of innovative leadership in public administration and the use of strategic planning in improving the mechanisms of public administration is confirmed by statistics.

Thus, in the context of the reform of the civil service and optimization and actual recertification of the corps of civil servants in spite of the announced 62.5 thousand tenders for vacant positions, $14 \%$ (or 8890 positions) were not replaced with a relatively sufficient competitive selection - 1.67 people/ position. The worst situation was observed with the replacement of senior positions in category "A". The search for anti-crisis managers and experts or reform specialists was complicated.

In 2018, an audit of the effectiveness of the use of state budget funds for the implementation of comprehensive public administration reform was also conducted, which was conducted in 10 


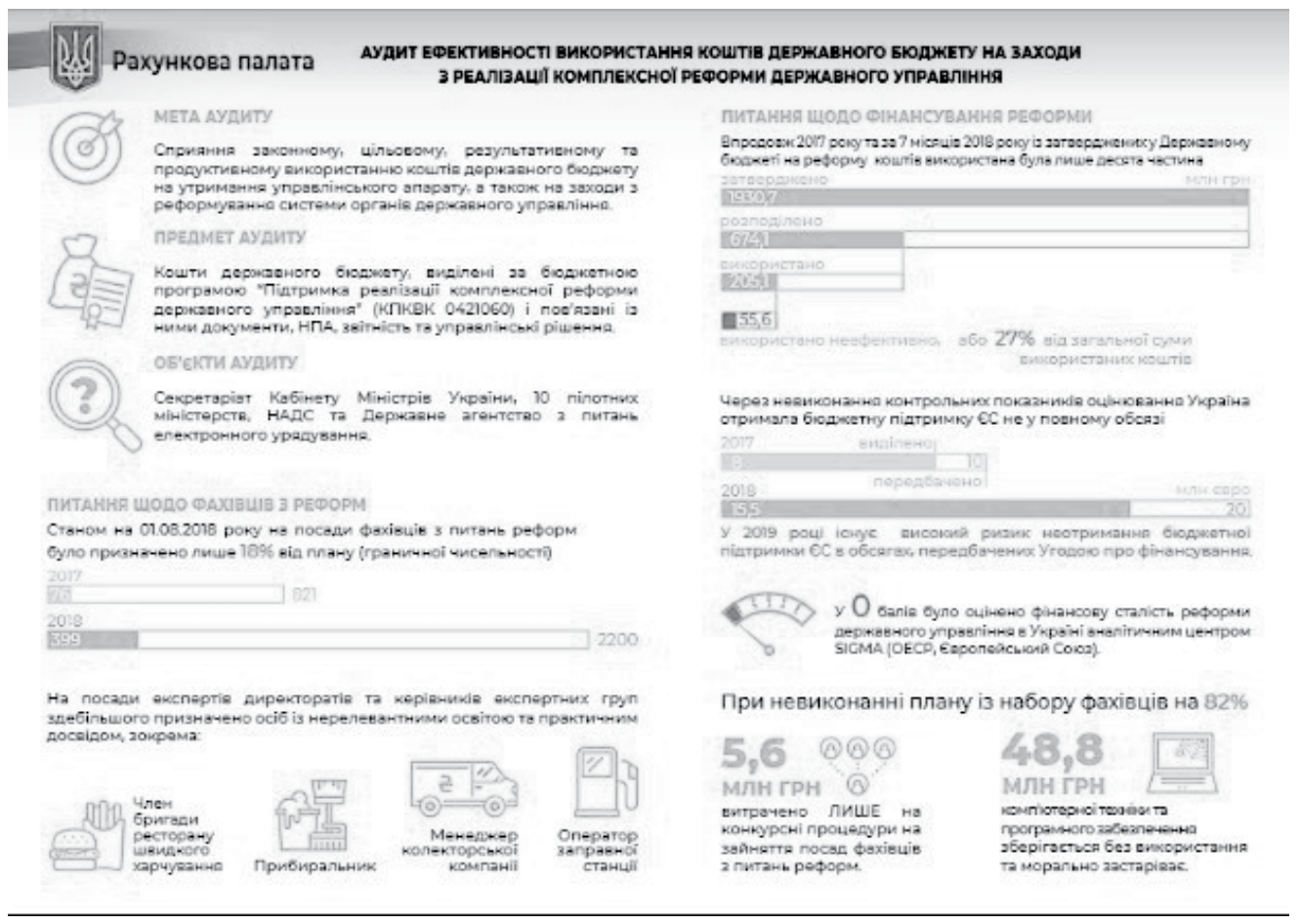

\section{Fig.1. Audit of the effectiveness of the use of state budget funds for the implementation of comprehensive public administration reform (Source: https://lb.ua/news/2018/10/24/410758_reforma_gosupra- vleniya_pod_ugrozoy.htm)}

ministries, two national agencies and the Secretariat of the Cabinet of Ministers.

The Report noted that in 2017-2018 it was planned to spend almost 2 billion UAH from the state budget and 300 million UAH on the reform of public administration. at the expense of EU budget support. "So, from 2200 people, who, according to the strategy of reforming of public administration of Ukraine for 2016-2020 approved by the Cabinet of Ministers should be hired to carry out reforms through ministries and National agencies in the relevant industries and areas, at the date of completion of the audit only 399 people, or $18 \%$ of the planned figure were employed... Reform without highly qualified personnel and proper funding is doomed to failure, especially with such a low level of implementation of measures" [2] the preservation of the existing problem will strengthen the irrational management in this area and the lack of professional management personnel for reforms in the state and development of Ukraine.

The basic requirements for the personality of a leader in the public service are grouped into three blocks of personal qualities:

1. Functional and role characteristics of the leader (aimed at the successful performance of duties): competence, the ability to see the future 
in the work, to take responsibility for decision-making, organizational skills, the desire to achieve success.

2. Communicative and business qualities: ability to work with people, companionship, flexibility in relations with colleagues.

3. Moral and ethical qualities: decency, commitment, diligence, honesty, integrity, diligence, responsibility, lawabiding.

All this is necessary but not sufficient to create innovative leaders. In substantiation of theoretical and methodological approaches to the transition to the model of innovative leadership in public administration, it is necessary to determine the framework of innovative leadership in public administration.

The innovative leader's profile consists of the fact that he:

- shapes the future and answers the strategic question-where are we going;

- explains to others the direction and strategies related to the overall goals and policies of the government;

- calculates which state institutions or structures should be successful;

- pragmatically checks ideas for existing resources (budget, human resources, other opportunities);

- creates innovation;

- inspires others to move from the present to the future.

Systemic, innovative leader, first of all:

- implements theory into practice (How do we make sure we get where we're going?);

- puts the strategy into action and puts the system in its place, showing an example to others;

- knows what key decisions to make and to whom to delegate;
- promotes effective teamwork;

- adheres to its promises to stakeholders

Secondly, an innovative leader:

- attracts today's talents (Who goes with us on this journey?);

- attracts, supports and inspires talents to show results;

- determines what skills are needed;

- attracts talent to organize and communicate intensively with others;

- makes sure that team members work according to their strengths.

Thirdly, an innovative leader:

- builds the next generation (Who will remain and support the public service in the next generation?);

- makes sure that the public sector has the long-term competencies necessary for future strategic success;

- establishes rules that demonstrate compliance with the promise to build the next generation of talent in the public sector;

- helps future leaders be successful;

- develops a work plan focused on future talents;

- helps team members see their future careers in the public sector.

Thus, an innovative leader:

- invests in himself - personal effectiveness;

- is not limited to what he knows or what he does.

The development of the model of innovative leadership in public administration in Ukraine is based on the world's leading experience. Thus, according to the report "Global innovation index" dated 2018, prepared together by Cornell University, INSEAD school of business and the world intellectual property organization (WIPO), the ranking of leading innovators is 
as follows: Switzerland (1st in 2017); Netherlands (3rd); Sweden (2nd); UK (5th); Singapore (7th); United States of America (4th); Finland (8th); Denmark (6th); Germany (9th); Ireland (10th); Israel (17th); Republic of Korea (11th); Japan (14th); Hong Kong (China) (16th); Luxembourg (12th); France (15th); China (22nd); Canada (19th); Norway (19th); Australia (23rd); Austria (20th); New Zealand (21st); Iceland (13th); Estonia( 25th); Belgium [3].

In foreign practice, it is the social responsibility of bodies and heads of administrative bodies that is the priority of their activities. Thus, a review of administrative reform cases in Canada, Australia and the UK, prepared by researchers from Northampton University, shows that the key features of the heads of state organizations are: openness and honesty, respect for the individual, self-esteem, the desire and ability to speak and listen to the interlocutor, a clear understanding of the consequences of decisions. The authors of the study emphasize that these qualities are a kind of ideal that can be achieved with a sufficiently high level of development of society, the readiness of state organizations to set strategic objectives for the long term, and not be limited to tactical decisions for the future of the next electoral cycle [4].

An ideal example of the role of ethical and moral qualities of a leader focused on the social responsibility of leaders in public organizations is the example of Denmark.

In 2010, Hansen and Villadsen, in their work on the management styles of managers in public and private companies, according to a survey of about 950 Danish managers, came to the con- clusion that the theory of leadership in public administration has not received due attention in the study of management theory. One of the important conclusions that Hansen and Villadsen came to is that due to the different management context and management models in public and private organizations the level of hierarchy, horizontal and vertical relationships - leadership styles differ. For example, in Danish public organizations, leaders are more often involved in decision-making and share responsibility with colleagues (participatory leadership), and in the private sector they prefer a directive style of leadership, often simply lowering the decisions taken from above [5].

The practical experience of Denmark, Canada, Australia and the United Kingdom clearly demonstrates another significant difference between governance in the public and commercial sectors, namely, social responsibility to citizens and responsibility for the consequences of decisions to them. This practice is characteristic of developed democratic systems, where one of the main factors of the success of public administration is the level of public confidence in the government [6].

The example of administration in Denmark is the exception rather than the rule. A detailed study conducted among USA Federal employees using the Bass and Avol questionnaire showed that managers in government organizations are more likely to have transactional leadership features, while leadership qualities associated with transformational leadership are much less common. However, these are transformational leadership qualities that have the greatest impact on subordi- 
nates and allow to achieve the greatest results in the process of work [7].

Conclusions and prospects for further research. Leaders are those who learn: from success, from defeat, from people, from life. Innovative leaders inspire loyalty and commitment. They act with integrity and trust.

Ukraine is building a democratic society. Thus, our model of governance should be based on the demand of citizens: to fight corruption, how to develop the sphere of education or how to develop the sphere of public procurement. Unfortunately, it is impossible to adopt a Western or Eastern model. We need our own way, a combination of successful practices of different countries. And we need innovative leaders of the state scale who are able to combine these best practices and implement them. But leaders are not born. We can and should create a system of development of innovative leaders in public administration, who will be able to successfully make the necessary further steps for the development of the country.

\section{REFERENCES}

1. Mpumalanga Senior Management Summit (2014), Ingwenyama, "Report on effective leadership in Public Administration and Resource Management”, Round table: Orange.

2. Dzherelo: https://lb.ua/news/2018/ 10/24/410758_reforma_gosupravleniya_pod_ugrozoy.htm

3. Global Innovation Index (2018).

4. Kakabadse, A. and Kakabadse, N. K. (2003), "Comparison of case studies examining the paucity of leadership in government", Ethics, values, and behaviors: Public Administration, vol. 81, no 3, pp. 477-508.
5. Hansen, J. R. and Villadsen, A. R. (2010), "Comparing Public and Private Managers' Leadership styles: Understanding the Role of Job Context”, International Public Management Journal.

6. Kupriashyn, H. L. (2003), "Hosudarstvennyj menedzhment: vozmozhnosty y ohranychenyia", Hosudarstvennoe upravlenye. Elektronnyj vestnyk.

7. Wart, V. M. Trottier, T. And Wang Xiaohu (2008), "Reinforcing the Need for More Sophistication in Leadership Studies in the Government”, Public Administration Review.

\section{СПИСОК ВИКОРИСТАНИХ ДЖЕРЕЛ}

1. Mpumalanga Senior Management Summit (2014), Ingwenyama, "Report on effective leadership in Public Administration and Resource Management", Round table: Orange.

2. Джерело: https://lb.ua/news/2018 /10/24/410758_reforma_gosupravleniya_pod_ugrozoy.htm

3. Global Innovation Index (2018).

4. Kakabadse, A. and Kakabadse, N. K. (2003), "Comparison of case studies examining the paucity of leadership in government”, Ethics, values, and behaviors: Public Administration, vol 81, no 3, pp.477-508.

5. Hansen, J. R. and Villadsen, A. R. (2010), "Comparing Public and Private Managers' Leadership styles: Understanding the Role of Job Context”, International Public Management Journal.

6. Купряшин, Г. Л. (2003), "Государственный менеджмент: возможности и ограничения", Государственное управление. Электронный вестник.

7. Wart, V. M. Trottier, T. And Wang Xiaohu (2008), "Reinforcing the Need for More Sophistication in Leadership Studies in the Government”, Public Administration Review. 